Kirja-arvio

\title{
Valokuvat historian toisin esittäjinä
}

\author{
Kalha, Harri (toim.). 2016. Kummat kuvat. Näkökulmia valokuvan kulttuureihin. \\ Tietolipas 251. Helsinki: Suomalaisen Kirjallisuuden Seura. 275 sivua.
}

\author{
Jari Kupiainen
}

$K^{\prime}$ ummat kuvat. Näkökulmia valokuvan kulttuureihin tarkastelee 1900-luvun alun eurooppalaista käyttökuvakulttuuria ja aikakauden kuvamediaa seitsemän kirjoittajan voimin. Teos kietoutuu erityisesti toimittajansa dosentti Harri Kalhan tutkimus- ja näyttelytoiminnan ympärille: yhdeksästä artikkelista kolme on Kalhan itsensä kirjoittamia, ja muutamissa muissa teksteissä hyödynnetään Kalhan aineistokokoelmaa eri tavoin. Teoksen taustalta ja mainintoina eri artikkeleissa löytyvät myös Kalhan tutkimus Ihmeja kumma (2012) sekä Kalhan näyttely Surrealismia ja silmänlumetta (Valokuvataiteen museo, 2013).

Artikkelit on jaettu kolmeen osaan, jotka jäsentävät teoksen keskeisiä painopisteitä. "Kummalliset käyttökuvat" koostuu Kalhan johdantoartikkelista ja lilliputtiartikkelista sekä näi-

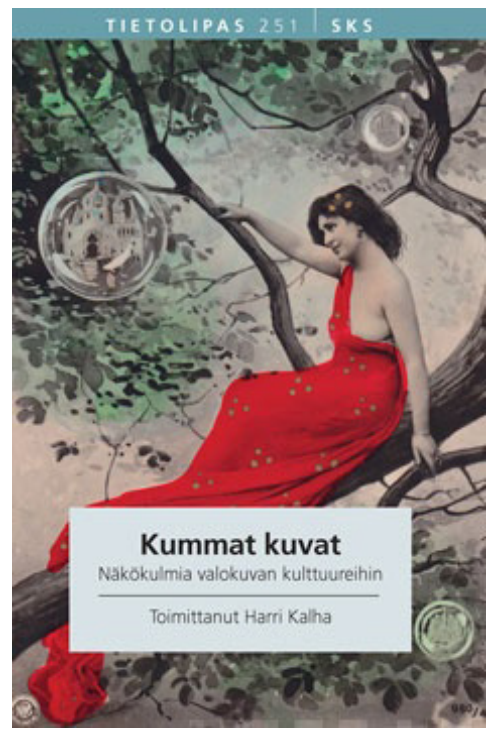
den väliin sijoittuvasta Max Fritzen post mortem -valokuvia käsittelevästä tekstistä. Toisessa osassa "Kuvat ja konteksti" käsitellään Georges Méliésin, Aleksandr Rodtšenkon ja Claude Cahunin taiteellista tuotantoa. Kolmas osa "Teoreettisia unelmia" keskittyy taide- ja kulttuuriteoreettisiin pohdintoihin etenkin Sigmund Freudin ja Walter Benjaminin tuella. Teoksen päättää Kalhan protosurrealismia käsittelevä taidehistoriallinen analyysi.

Kummat kuvat -teoksen keskiössä ovat 1900-luvun alun eurooppalaisen käyttökuvakulttuurin osalta erityisesti postikortit, joita Kalha on kerännyt etenkin berliiniläisistä divareista, kuten "Terveisiä lilliputtien maasta"-artikkelissa kerrotaan. Teoksessa analysoidut postikortit edustavat varsinkin eroottisia ja fantasia-aiheita sekä "toiseutta", jolloin Kalhan - ja muidenkin teoksen kirjoittajien - huomio suuntautuu sukupuolen esittämisen käytäntöihin, murtumiin ja monimerkityksisiin viittaussuhteisiin. Niiden avulla kortteja ja valokuvia paikannetaan suhteessa moderniteettiin ja taidehistoriaan sekä muodostuvaan kuvamediaan, mediakulttuuriin ja modernisoituvaan eurooppalaiseen yhteiskuntaan. Itse asiassa Kummien kuvien maantieteellinen fokus keskittyy lopulta korostuneesti keskiseen Eurooppaan 
muutamaa Yhdysvaltojen tilannetta koskevaa mainintaa lukuun ottamatta. Esimerkiksi suomalaisia kuva-aineistoja ei teoksessa tarkastella.

\section{Tekniikkaa ja magiaa}

Kalha paikantaa johdannossa postikorttiaineiston fantasia-aiheineen osaksi sitä kamppailua, jota maalaustaide ja valokuvaus kävivät keskinäisistä suhteistaan ja kulttuurisesta elintilasta:

Kamerasta, joka oli yritetty karsinoida realismin tallentajaksi, tuli hetkeksi vallattoman mielikuvituksen väline. Moderni maailma syventyi kollektiiviseen unennäköön. Samalla arki tarttui taikauskoon ja omaksui moderneimmat tekniset välineet mielikuvitusmaailman todentamiseen. (Mt. 19.)

Tämän näkökulman erittely teoksessa etenee sitten etupäässä taidehistoriallisten sekä taide- ja kulttuuriteoreettisten ajatusten ohjaamana. Samalla teoksen tekstit oikeastaan varsin yllättävästi ohittavat monia valokuvan ja yhteiskuntatieteiden tutkimuksia, jotka olisivat teoksen eri artikkeleissa luontevasti auttaneet syventämään ja monipuolistamaan sekä kuva-aineistojen kontekstualisointia ympäröivään yhteiskuntaan että yhteiskuntakehityksestä esitettyjä näkemyksiä. Esimerkiksi "taikauskon" käsite toistuu teksteissä reflektoimattomana, lähinnä modernisaatiota kontrastoivana retorisena käsitteenä. Silti kirjoittajat eivät viittaa vaikkapa Bruno Latourin tunnettuun teokseen Emme ole koskaan olleet moderneja (1991/1993, suom. 2006), joka osoittaa tällaisen jaottelun onttouden modernissa yhteiskunnassa.

\section{Kuoleman ja toiseuden kuvastot}

Max Fritze tarkastelee viktoriaanista post mortem -valokuvausperinnettä ja keskittyy lähinnä 1860-luvun daguerrotypia-valokuviin ja aikakauteen, jolloin valokuvaus yleistyi nopeasti 1840-luvulta alkaen eri kansankerroksiin. Daguerrotypiatkin vaihtuivat teknologian kehittyessä uusiin formaatteihin. Esimerkiksi myöhempi carte de visite -kuvatekniikka lisäsi valokuvauksen suosiota. Post mortem -kuvat tulivat tuolloin muotiin keinoina tallentaa viimeinen muisto kuolemaisillaan olevasta tai juuri kuolleesta (pre/post mortem) sukulaisesta tuomaan lohtua omaisille. Nykyaikaan näitä kuvia on säilynyt vähän (ks. kuitenkin The Thanatos Archive: https://thanatos.net/).

Kuolleita esittävien valokuvien tradition taustalta on osoitettavissa keskiaikainen artes morendi -maalausperinne sekä kuvataiteiden laajempi surumaalausten traditio vakiintuneine allegorioineen. Kuolleita esittävien valokuvien suosio jatkui koko $1800-l u v u n$ jälkipuolen ja yleistyi entisestään uusien kuvaustekniikoiden ja laitteiden myötä viimeistään 1888 jälkeen Kodak-kameroiden ja kansanvalokuvauksen leviämisen mukana. Kuitenkin näiden kuvien suosio alkoi hiipua vuosisadan taitteen jälkeen ja loppui kokonaan ensimmäisen maailmansodan myötä ja osin jo aiemmin. Eurooppalaisten suhde kuolemaan, kuolemiseen ja kuolleiden läsnäoloon yhteiskunnassa muuttui, ja kuolemaa alettiin häivyttää näkyvistä. Post mortem -kuvat työllistivät valokuvaajia vuosikymmenten ajan, ja kuvauskäytännöt kehittyivät nopeasti "nykyaikaisiksi": romantisointi, lavastaminen, sommitelmat, kuvien muokkaus ja retusointi sekä muut kuvamanipulaation tekniikat olivat yleisessä käytössä. Erityisen tavallista oli kuoleman ja unen visuaalinen samastaminen. 
"Terveisiä lilliputtien maasta: pieni tutkimusmatkamatka toiseuteen" -artikkelissa Kalha palaa takaisin johdannon keskeisiin teemoihin, nyt erityisesti pienikokoisia ihmisiä esittävän valokuva- ja postikorttiaineiston avulla. Tekstissä tarkastellaan myös yhdysvaltalaisen journalistin P. Richardsin vuonna 1912 Berliinissä julkaistua teosta, joka popularisoi aihetta saksankieliselle yleisölle. Ensimmäinen toiseuden erittelyn teema tässä on nimeäminen: esimerkiksi lilliputit, kääpiöt ja friikit ovat vakiintuneet kieleen pienikasvuisia ihmisiä leimaaviksi pejoratiivisiksi, kielteisiksi mielikuviksi. Kuinka tätä käsitteistöä voidaan kontekstualisoida ja purkaa, ja mitä näkökulmia stereotypiat avaavat eurooppalaisiin käsityksiin toiseudesta?

Rakentuvat kysymyksenasettelut ovat olennaisia ja kytkeytyvät myös monipuolisesti eurooppalaiseen kolonialismiin, ulkoeurooppalaisten kansojen edustajista, vammaisista ja geneettisistä poikkeavuuksista koottuihin "ihmistarhoihin" ja teemapuistoihin, valokuvauksen historiaan, lääketieteen ja ihmistieteiden kehitykseen sekä 1800-luvulla käynnistyneeseen mediakulttuuriin. Kalha tuo näitä näkökulmia esiin vain osittain huomion keskittyessä erityisesti Berliinissä 1920-30-luvuilla toimineen "lilliputin satukaupungin" vaiheiden jäljittämiseen postikorttien tukemana; vastaava turisti- tai attraktiokohde sijaitsi myös Pariisissa. Aihe on kiinnostava, ja Kalhan lennokas kirjoitustyyli pääsee oikeuksiinsa pohdinnoissa söpöydestä ja groteskista. Sen sijaan kuriositeettikäsitteen osalta tarkastelu jää pinnalliseksi ohittaen vaikkapa eurooppalaisia 1400-luvulta alkaneita kolonialistisia kuriositeettikokoelmia koskevat historialliset tutkimukset - kuriositeettikokoelmat johtivat aikanaan eurooppalaisen museoinstituution muodostumiseen.

\section{Kuvallisuuden uusia suuntia}

Toisen osan avaa Sandra Lindblomin analyysi ranskalaisen elokuvaohjaaja Georges Méliésin taiteellisesta työstä verrokkiaineistona aikakauden fantasiapostikortit. Huomio on Méliésin innovatiivisissa tavoissa työskennellä kaksi- ja kolmiulotteisten pintojen avulla ja rakentaa elokuvallisia trikkejä tilallisuutta ja pinta-syvyys -vaihtelua hyödyntäen. Méliés hyödynsi teatterin ja maalaustaiteen konventioita. Teoksiin lisättiin graafisia elementtejä, ja filmejä väritettiin käsin. Vastaavia keinoja käytettiin myös postikorteissa, kuten Lindblom tuo oivaltavasti esiin. Teksti on huolellisesti laadittu ja ilmentää monipuolisen oppineesti tekijänsä perehtyneisyyttä aiheeseensa.

lina Schwanck tarkastelee avantgardisti-taiteilija Aleksandr Rodtšenkon asemaa neuvostoliittolaisen valokuvaus- ja kuvataiteen kehityksessä 1920- ja 30-luvuilla. Teksti paikantaa Rodtšenkon roolia "tulevaisuuden taiteen" kehittämisessä sekä asemaa vasemmistolaisten taiteilija-aktivistien LEF-ryhmässä. Ryhmän ajatukset amatöörivalokuvauksen tärkeydestä vallankumouksen edistämisessä sekä sosiaalista todellisuutta dokumentoivasta "kinosilmästä" tulivat laajalti tunnetuiksi, ja ne vaikuttivat Kinokit-ryhmän myötä elokuvataiteen kehitykseen.

Ilona Räihä esittelee ranskalaisen taiteilijan Claude Cahunin (1894-1954) elämää ja tuotantoa. Lucy Schwob omaksui teini-ikäisenä itselleen androgyynin taiteilijanimen Claude Cahun, jolla kirjallisesti lahjakas taiteilija sai huomiota jo nuorena ja onnistui ensimmäisenä naisena julkaisemaan tekstejään arvostetussa kirjallisuuslehdessä. Dadaan ja surrealismiin liitetty taiteilija tunnetaan etenkin omakuvistaan, joiden valokuvaamisen Cahun aloitti jo nuorena. Sittemmin hän laati lukuisia kollaasitekniikoita hyödyntäviä esinesommitelmia (assemblage); ne olivat ainoita taideteoksia, jotka hän esitti näyttelyissä elinaikanaan. 
Muiden surrealistien tavoin Cahunia kiinnostivat myös ulkoeurooppalaiset taidemuodot ja teokset, joita oli esillä Musée de l'Hommessa Pariisissa.

\section{Kummat kuvat teoriassa ja taidehistoriassa}

Kummien kuvien viimeisessä osassa Pirkko Linder tarkastelee postikorttikokoelmaa suhteessa Sigmund Freudin elämään ja ajatuksiin. Ohittaen samalla hyllymetreittäin aihealueen kirjallisuutta Linder keskittyy yhtäältä Freudin omiin valokuvia sekä postikortteja koskeviin mainintoihin ja toisaalta psykoterapeuttiseen ammattiosaamiseen. Analyysi nostaa esiin niitä kuvien affektikytköksiä, joita kuva-aiheet eri tavoin asettavat katsojan tarkasteltavaksi ja ennen muuta katsojan tiedostettuihin tai tiedostamattomiin haluihin ja tunteisiin vetoaviksi. Tarkastelussaan Linder hyödyntää varsinkin Freudin ajatuksia unien ja vitsien tehtävistä psyyken toiminnassa.

Petra Lehtoruusu esittelee fantasmagorian käsitteen Walter Benjaminin ajattelussa ja soveltaa sitä postikorttien analyysiin - Benjamin itse oli kiinnostunut käyttökuvien kulttuurista ja kirjoitti populaarikulttuurisista aiheista monipuolisesti. Fantasmagorialla viitattiin "nautinnolliseen lumeeseen". Sellaiset Theodor Adorno määritteli marxilaiseen teoriaan nojaten hyödykkeiksi tai teoksiksi, jotka peittävät kaikki tuotantoprosessinsa jäljet; niistä ei voi päätellä, miten ne on valmistettu. Tällainen "tuotantoprosessin piilottaminen" koskee toki laajasti teollista tavaratuotantoa mutta myös kaupallista kulttuurituotantoa. Artikkelissa paikannetaan Benjaminin kiinnostuksen aiheita kuvakulttuurin, erilaisten panoraamojen sekä maailmannäyttelyjen fantasmagorisen spektaakkelikulttuurin berliiniläisessä keskiössä.

Teoksen päättää Harri Kalhan taidehistoriaa uudelleen kirjoittava "Tulevaisuuden uni", joka tarkastelee surrealismia edeltänyttä kahta vuosikymmentä ajankohdan käyttökuvakulttuurin avulla. Teoksen teoreettisesti kunnianhimoisin artikkeli piirtää aikakauden eurooppalaisesta kuvakulttuurista oppineen ja asiantuntevan analyysin, joka syventää edellisen artikkelin Benjamin-teemaa. Kalha kirjoittaa postikorteista ja käyttökuvista osoittaen paralleeleja dadan ja surrealismin maalaus- ja ilmaisukonventioiden sekä niitä ajallisesti edeltävien valokuvapostikorttien hyödyntämien graafisten tekniikoiden välillä. Keskiössä ovat myös taidekriitikko Clement Greenbergin vaikutusvaltaiset tulkinnat modernin taiteen luonteesta. Teksti haastaa vakiintuneita käsityksiä modernististen kuvataidesuuntausten kehitysvaiheista ja problematisoi monipuolisesti käyttökuvan ja taidekuvan välisen jaottelun. Toivottavasti artikkeli toimii luonnoksena aihetta käsittelevälle myöhemmälle systemaattiselle tutkimukselle.

Kummat kuvat tarjoaa lukijalle antoisan ja sivistyneen taide- ja kulttuurihistoriallisen tutkimusmatkan 1900-luvun alkuvuosikymmenten eurooppalaiseen kuvakulttuuriin. Rajaus pysyy tiiviisti läpi koko teoksen, ja toisinaan tämä tiivistyy myös tarkastelun kaventumiseen lähinnä taidehistorian lähteisiin. Kummien kuvien aineistoytimessä ovat lopulta valokuvat ja valokuvien historiaan kytkeytyvä tutkimusnäkökulma. Tämän vuoksi tuntuu puutteelta, että Elisabeth Edwardsin, W. J. T. Mitchellin tai Christopher Pinneyn kaltaisia valokuvatutkijoita ei hyödynnetä teoksessa ollenkaan. Näiden ja muiden valokuvahistorian tutkijoiden teksteillä tuettuna monet Kummissa kuvissa esitetyt asiat olisi saatu nykyistä paremmin paikannettua historiallisiin ja yhteiskunnallisiin yhteyksiinsä, joiden osia myös taide ja kuvakulttuuri ovat. 
Kummat kuvat. Näkökulmia valokuvan kulttuureihin sopii taidehistorian, valokuvatutkimuksen ja visuaalisen mediakulttuurin syventäväksi oheislukemistoksi ja oppimateriaaliksi. Teoksen artikkelit haastavat lukijaa miettimään uusiksi luutuneita taidehistoriallisia käsityksiä ja tunnistamaan paremmin historiallisten aikakausien kuviin liittyviä monimuotoisia yhteiskunnallisia, kulttuurisia ja taidehistoriallisia suhteita sekä kuvien omissa aikalaiskonteksteissa että osana kuvamedian nykyaikaisia tulkintoja. Monet lukijat pitävät myös kuvatulkintojen elävästä ja sivistyneen lennokkaasta kirjallisesta tyylistä, joka luonnehtii teoksen useimpia tekstejä.

\section{Kirjallisuus}

Kalha, Harri. 2012. Ihme ja kumma. surrealismia ja silmänlumetta 1900-luvun alun postikorttitaiteessa. Helsinki: WSOY.

Latour, Bruno. 2006 (1991/1993). Emme ole koskaan olleet moderneja. Nous n'avons jamais été modernes. Suom. Risto Suikkanen. Tampere: Vastapaino.

Jari Kupiainen (FT) työskentelee Karelia-ammattikorkeakoulun mediakoulutuksen yliopettajana. Hän on Itä-Suomen yliopiston kulttuurin tutkimuksen dosentti, Viscult-elokuvafestivaalin johtaja ja toimittanut yhdessä Liisa Häkkisen kanssa teoksen Kuvatut kulttuurit. Johdatus visuaaliseen antropologiaan (Suomalaisen Kirjallisuuden Seura, 2017). 